\title{
Editorial \\ De-professionalism, identity and the productivity debate: A research puzzle?
}

\section{Nigel Malin}

In a recent letter to the Financial Times a group of left-leaning economists said that the Labour Party's radical manifesto is justified by 'Britain's array of structural problems, including a lost decade for productivity growth, a dearth of investment and the gulf between London and the south-east and the rest of the country' (Blanchflower and others, 2019). Given that the newly elected Conservative Government espouses the language of easing austerity, a key research question for social policy might be

What should be the rationale for embedding professionalism and employing more professional workers as a solution to raising productivity in a re-configured welfare state?'

The concept of de-professionalisation has become defined multi-dimensionally as follows to include:

- removal of professional control, influence, manipulation; de-stabilisation of their mode of professionalisation and of their professional ties (Demailly and De La Broise, 2009). In practice unalloyed de-professionalisation produces a sharp diminution of autonomy at work and a collective powerlessness to conceive of any positive reconstitution of a lost professionalism (Adcroft and Willis, 2006, Frostenson, 2015).

- discrediting or deprivation of professional status, also privately experienced as a weakening of status, respect or tendency away from a position of strength or equal status. It is associated with measures for lessening the need for specialist knowledge and expertise (Delamotte, 2016; Rogers and Pilgrim, 2014; UEA Centre for the Creative and the Critical, 2018).

- an obverse of professionalisation, in which it is assumed that there is a plurality of professionalisation processes (Demailly, 2003, Kuhlmann and Saks, 2008); otherwise regarded as a function or by-product of a normally hierarchical process where certain jobs become vulnerable, subordinate and professional identity scapegoated, replaced by insecurity and a lack of belonging - the 'precariat' (Standing, 2014); or a loosening of bonds of trust and commitment, divorcing a person's will from his or her behaviour (Sennett, 1998).

De-professionalisation is the systematic de-skilling of professional positions, a process that has created a conflict between character and experience of disjointed time 
threatening the ability of people to form their characters into sustained narratives. It is a process which occurs in a workplace or industry when non-qualified or less-qualified individuals are used to perform work which is more properly performed by appropriately qualified individuals. This devaluing of professional work replaces the requirement for professional qualifications with 'generic classifications' not requiring specific qualifications. Central to this argument is the proposition that de-professionalism becomes defined by low productivity where a rise in low-skilled jobs is blamed for static wages, where low economic value is associated with low status (Avis, 2018; Chakrabortty, 2016; Elliott, 2015).

Reversing the impact of processes that have led to de-professionalisation of the workforce would improve productivity along with the quality of work conditions experienced by employees (GOV.UK Taylor Review, 2017; Skidelsky, 2019). Focusing on the willingness or desire of the state to change things, it has been argued recently by one leading historian that the modern British state has distanced itself from the productive economy (Edgerton, 2019). Evidenced partly by stagnant wages and productivity, this author suggests that the state or central government is barely able to take an expert view of the complexities of modern capitalism. Further - painfully clear - evidence was provided of this ineffectualness in the Brexit impact sectoral reports, that the Conservative Government was forced to publish, namely Yellowhammer (Stewart and Walker, 2019). These showed that a no-deal Brexit could result in rising food and fuel prices, disruption to medicine supplies and public disorder on Britain's streets.

Productivity is considered the single most important determinant of a country's standard of living and lack of growth limits a country's ability to become richer. It has failed to recover since the 2008 financial crisis and has weakened since the Brexit Referendum, contracting particularly since 2018 (Romei, 2019). As regards assessing its impact on public sector services, productivity has been identified as an individualised professional activity, as for example improved healthcare productivity becomes a fundamental objective of policy and professional work (Moffat, Martin and Timmons, 2014). In the context of transforming public services such as health, social care, education and criminal justice, ideas about how to achieve better productivity are now framed as a response to failure to engage professionals (Boitnott, 2015; Robertson-Smith and Markwick, 2009). As such 'new productivity narratives' are required as direct appeal to professionalism (Kopasker, Montagna and Bender, 2019). The 'productivity puzzle' poses questions such as:

- what impact do issues such as pay, perceptions of pay, job security, progression opportunities, use of skills, supportive colleagues, the quality of line-management and employee engagement have on productivity?

- when are productivity and the quality of work experienced by employees mutually reinforcing, or when are these goals in tension? 
In the UK the rise in whole-economy pay has been held back in recent years by the $1 \%$ cap on public sector pay, which arithmetically, has lowered whole-economy pay and growth. Here the argument is to support human capital, skills and staff transfers, through mentoring or twinning and creating formal networks for knowledge exchange among sectors, regions and organisations (Haldane, 2018). This would support a diffusion, innovation and productivity growth infrastructure throughout. Programmes of investment in public services only add value if the problem of how to address acute shortages of trained staff is resolved. Building either a new school or hospital would not in itself increase the productive capacity of this sector. A drive for efficiencies, value for money, de-regulation set in a context of increased globalisation has led to outsourcing low paid jobs that are characterised as having poor entitlement to work benefits.

Employing more overseas trainees could help to tackle NHS staff shortages and thereby reduce the strain on the service. For example the pressure on medical professionals to provide quality care when there's simply not enough staff is causing the NHS to buckle. As demand grows, under-supported staff appear to be leaving in droves. Short-sighted cost-cutting in children's services by failure to invest in employing trained professionals can render a service ineffective and unsafe. Systems of delivery become chaotic and dysfunctional - take for example our youth justice system, the cancellation of appointments on a large scale in child mental health services, the sizeable reduction in the number of hospital beds (17,230 since 2010) or the management of some care homes. Poor building and inadequate equipment can disable professionals from fulfilling their role properly.

Encapsulated in the main research question is an exploration of professional identity, seemingly traduced during austerity years, along with its consequences, which include entrepreneurialism as a means for enhancing productivity. Increases in productivity, which is output per unit of input employed, are as a result of deploying better raw materials, better trained or educated labour or better machines even if no changes in factor qualities or proportions take place (Lipsey, 1979). New ideas can raise efficiency by being applied to a new product and for most UK employers lowering the cost of production may be seen as an obvious benefit. This however usually produces a degrading effect upon the technical capacity of the worker. In 2016 Conservative Government Chancellor Hammond dedicated his first Autumn statement to tackling the productivity gap, to develop a set of interventions aimed to drive up job quality and productivity simultaneously. In recognition of a range of labour market challenges like low pay, lack of opportunities for progression and representation, and worker insecurity, the UK Government committed in its Industrial Strategy to 'continuous improvement in the quality of jobs, with the UK reaping the rewards in terms of advanced growth and productivity' (HM Government, 2017).

The nature of the productivity debate suggests that in recent years this has been seen by many as the root of all the UK economy's problems (Avis, 2018; Haldane, 2018). What may be less understood however is how this might translate to the public sector and service-driven industries, such as health, social care, education and criminal 
justice. It should not be taken for granted that the levers for improving productivity are always compatible with the aim of improving job quality. In the world of work the phrase may be understood to mean 'making work more efficient', 'delivering more for less', or perhaps simply (and problematically) 'working harder'. Links and trade-offs between different aspects of job quality and productivity are far from clear-cut (Irvine, 2019). For example one employer might conclude that raising wages will motivate employees to give their best at work; another might decide to focus on employer engagement channels; another might decide to bring in stressful and punitive targets or intrusive workplace monitoring; or even to lay off workers and bring in technology which may get the job done faster.

\section{How do we measure productivity of professionals employed in the public sector?}

Productivity measurement should focus on overall capabilities, not on one set of costs. It measures the efficiency of an organisation's production process, calculated by dividing the outputs produced by the inputs used in its production process. Common inputs are labour hours, capital and natural resources. In the public sector this translates to investing in staff by offering specialist training, providing greater security and enhancing pay and conditions. Outputs are generally measured in sales or the number of goods and services produced. In the public sector this translates for example into the number of hospital treatments given, the quality of care patients receive, the number of students taught or modules delivered, or the number of disabled individuals who receive an effective needs assessment.

Geoff Mulgan's recent book, Social Innovation: How societies find the power to change, employs the term 'social production systems' where social action requires 'the right level of granularity' for its analysis. Suggested inputs here include the individual social entrepreneur providing the organisation with money and freedoms, the enterprise or non-governmental organisation (NGO) helping it to grow and the individual innovation, helping it to spread and scale (Mulgan, 2019, p. 94). This author refers to 'unhealthy patterns' which include poor skills and little spending on training; slow adoption of technologies and local monopolies which would need to be addressed in order to improve the functioning of the production system. An overall main argument is for matching research and development in technology and science with a socially focused development that harnesses creative imagination on a larger scale.

Introducing an analysis of de-professionalism into the productivity debate offers a widened understanding of the parameters defining this subject area. Inputs may be represented as service 'costs' as the legitimate price paid to achieve a given level of productivity. Factors detracting from or reducing the efficacy of specific inputs would ultimately impact on productivity. For the NHS these should include a shortage of 
trained nurses or the number of individuals presenting as willing to train since the bursary for nursing degrees was abolished in 2017- the number of nursing vacancies in the NHS has been estimated at 44,000 (Fazackerley, 2019). The marketisation of public services has created increased job insecurity and de-regulation-for example in universities there has been an expanding casualisation of higher education staff, with $70 \%$ of research staff on temporary contracts, and many academic staff not entitled to holiday pay, maternity pay, annual leave or a pension (Chowdhury, Bhambra, Gopal, 2019; Elliott and Inman, 2019).

If the level of productivity were to be improved then such 'costs' for delivering services would need to be addressed. Shortages of staff and under-investment, and a lack of capability in front-line officers have been given as reasons why UK public services are currently failing. For example a failure to enforce community sentences and to put adequate resources and proper training into probation services and rehabilitation has been presented as relating to rising crime (Dearden, 2018). Similarly a lack of efficacy in the process of delivering post-custodial mental health or risk assessments has been seen as an important part of the narrative in contributing to serial killings (Morris, 2019).

It may become too complex an activity trying to obtain a productivity index from analysing the work of public service professionals (Nolan, 2017). This term has been defined by how good an organisation is at taking a sum total of raw materials, equipment, groups of employees and turning out useful goods and services. It is therefore, as much as possible, a relationship between physical inputs and outputs. As productivity is intertwined with technology, an organisation can improve its productive efficiency, for example by improving its technical efficiency - giving staff the right tools to carry out their work, budgeting for equipment and training (Coppersmith, 2019; Work Foundation, 2018). Employers have the power to improve productivity through improved management which actualises recognition of negative impacts on worker activity and failures to motivate or empower. It may also result in more engagement practices to help employees feel valued and assist morale (Miller, 2018; Nutcache, 2019).

Having outlined the rough contours of the productivity debate to elucidate a research question, this Issue of Social Work and Social Sciences Review presents five original articles that similarly address important research questions and all imply an urgency for conceptual clarity. A first article by Powell, 'The Eureka Moment? The creation of the British welfare state' examines the definitions of the welfare state and outlines the methods and criteria used in exploring the establishment of welfare states. This article discusses specifically the criteria applied to the British welfare state, for example expenditure, legislation, content and social citizenship, before analysing the arguments for 'different creation periods', for example Old Poor Law, nineteenth century, Liberal reforms, inter-war period, 1945 and later periods. The conclusion suggests that there 
still exists serious doubt over what the exact combination of circumstances in Britain were in 1945 which evoked that cry of 'Eureka!', that sudden understanding of a previously incomprehensible problem.

A second article by Smeeton, 'In search of social work's post-risk paradigm' describes a fundamental change in the basic concepts and experimental practices, namely a paradigmatic shift in child protection practice within the UK. He goes on to argue that this has resulted in a move away from the risk paradigm but that its replacement is not yet defined. The argument presented is that the risk paradigm is unsustainable and evidentially has created an essential tension within the profession. It follows that there is not yet a coherent perspective to replace the risk paradigm and practitioners are left with a tool-kit of technical interventions to guide their practice. The author concludes that what social work lacks is capacity to develop an ethic of practice due to a failure in the UK to engage with certain philosophical questions as regards its remit.

In the third article, 'Strategies for family engagement in evidence-based programmes: a meta-synthesis of systematic reviews from a social casework approach', Nevot-Caldentey, Socias and Brage explore the role of social work practice in youth risk prevention through evidence-based interventions, such as the Strengthening Families Programme, as undertaken in parts of Spain. Research findings are presented to show that evidence-based interventions applied at the family level can delay onset of substance use. The goal of the research reported in this article was to identify the most effective strategy for engaging families as regards social casework. Through a metasynthesis of two exploratory reviews, the article concludes with a focused discussion of the 'family factors' that social workers should consider in the process of building supportive relationships.

A fourth article by Deacon, MacDonald and colleagues, 'The Loss: conceptualising biographical experiences of disability, social isolation and emotional loneliness in North-East England' explores a conceptualisation of experiences of disability from a wide age group through biographical narrative interviews. Key risk factors were identified relating to disabled participants' experiences of loss in terms of 'ability', 'social connectivity', 'self-confidence' and 'loss due to bereavement'. This article explores the notion of emotional loneliness by focusing on removing 'disabling barriers' in a community context and by fostering 'relationship-building'. The term 'emotional loneliness' signifies different kinds of loneliness, where having poor quality relationships becomes associated with greater distress than having too few.

In the final article, 'Deliver us from evil: the role of faith and family in coping with stress among African migrants in Australia', Ikafa and Hack-Polay reports findings from an empirical study aimed to examine stressors affecting involuntary and voluntary African migrants in Australia and how they coped with stress. Participants used diverse coping strategies including a 'reliance of divine intervention and family usually constructed by alliance rather than kinship'. This article focuses on the significance of faith and family as remedies to 'deliver' the migrants from the obstacles to effective 
resettlement and psychological healing. The conclusion raises issues for social work practice as regards the need for child protection which might result from domestic violence and argues for understanding of migrant families' 'cultural differences' in investigating the source of these problems.

\section{References}

Adcroft, A. and Willis, R. (2006) Postmodernism, de-professionalisation and commodification (The outcomes of performance measurement in higher education). Journal of Finance and Management in Public Services, 6,1 43-60

Avis, P (2018) The great British productivity debate. HR News, September 10th

Blanchflower and others -Profs Chick, Desai, Griffith-Jones and Wren-Lewis (2019) Letter: As economists we believe the Labour Party deserves to form the next UK Government. Financial Times, November 26th

Boitnott, J. (2015) Productivity - Six Effective Ways to Enhance Workplace Productivity. @jboitnott March 10th. www.inc.com> john-boitnott> 6-effective-ways-to-enhanceworkplaceproductivity

Chakrabortty, A (2016) We're watching the death of neoliberalism - from within. The Guardian, March 14th

Chowdhury, T, Bhambra, G. and Gopal, P. (2019) gu.com/letters. The Guardian, December 3rd Coppersmith, K (2019) How Technology Improves Workplace Productivity. Business and Finances Human Resources, February 7th. www.business2community.com $>$ humanresources $>$ how-technology-improves-workplace-productivity

Dearden, L (2018) Private probation companies letting convicts commit more crime and allowing them to disappear, report finds. The Independent, February 9th

Delamotte, E (2016) De la professionalisation à l' industrialisation. [from Professionalisation to Industrialisation] in Pierre Moeglin (ed.) L'industrialisation de la formation.État de la question, Centre de National de Documentation Pédagogique, p75-92 Actes et Rapports pour l'éducation 2-240-0060-4 Available at : http://hal.archive-ouvertes.fr/hal-01387562

Demailly, L (2003) L'évaluation De L'action éducative comme apprentissage et négociation. Revue Française de Pédagogie, 142, 1, 115-129

Demailly, L and De La Broise, P (2009) Les enjeux de la de-professionalisation. Études de cas et pistes de travail. Socio-Logos, Revue De L'Association Française de Sociologie, 4.online 7 May http://socio-logos.revues-org/2305

Edgerton, D (2019) The Rise and Fall of the British Nation. Harmondsworth: Penguin/Random House

Elliott, L (2015) Rise in low-skilled jobs blamed for static wages. The Guardian, September 24th

Elliott, L and Inman, P (2019) Tories have hidden agenda to copy Trump - TUC Chief. The Guardian, November 26th 
Fazakerley, A (2019) Nursing crisis: Universities warned Cameron in 2011 that cuts would cause shortage. The Guardian, December 3rd

Frostenson, M. (2015) Three forms of professional autonomy: De-professionalisation of teachers in a new light, in autonomy in education. NordSTEP, Nordic Journal of Studies in Educational Policy. July 3rd. 1: 28464

GOV. UK (2017) Good Work: The Taylor Review of Modern Working Practices. An independent review of modern working practices by Matthew Taylor, Chief Executive of the RSA, July 11th Department for Business, Energy and Industrial Strategy

Haldane, A (2018) Bank of England Speech. The UK's productivity problem: Hub no spokes. Academy of Social Sciences Annual Lecture, London, June 28th

HM Government (2017) Industrial Strategy: Building a Britain fit for the future. Cm 9528. November. Department of Business, Energy and Industrial Strategy

Irvine, G (2019) Changing the Productivity Debate - New Carnegie UK Trust -RSA Partnership to Focus on Job Quality. Royal Society of Arts, April 17th

Kopasker, D, Montagna, C and Bender, K (2019) Insecure Lock-In: The Mental Health Effects of Anticipating Insecure Employment. Discussion Papers in Economics and Finance, 19, Vol 7, 2-19, 7edn. Aberdeen: University of Aberdeen

Kuhlmann, E and Saks, M (Eds.) (2008) Rethinking Professional Governance: International directions in health care. Bristol: The Policy Press

Lipsey, R (1979) An Introduction to Positive Economics. (5th ed.) London: Weidenfeld and Nicolson

Miller, B (2018) How to make employees feel valued. HR Daily Adviser. December 27th hrdailyadviser.blr.com>2018/12/27>how-to-make-employees-feel-valued

Moffat, F, Martin, P and Timmons, S (2014) Constructing notions of healthcare productivity: The call for a new professionalism. Sociology of Health and Illness. 36, 5, 686-702

Morris, S (2019) Triple killer cleared of murder due to insanity. The Guardian 3rd December

Mulgan, G (2019) Social Innovation: How societies find the power to change. Bristol: The Policy Press

Nolan, P (2017) How can we better measure public sector productivity? Public Finance International. February 23rd www.publicfinanceinternational.org $>$ news $>2017 / 02>$ howcan-we-better-measure-public-sector-productivity

Nutcache (2019) How to engage employees: A complete guide for managers www. nutcache. com $>$ blog $>$ how-to-engage-employees May 28th

Romei, V (2019) Fall in UK labour productivity is worst in 5 years. Financial Times, October 8th

Robertson-Smith, G and Markwick, C (2009) Employee Engagement: A review of current thinking. report 469. Brighton: University of Sussex, IES Network. Institute for Employment Studies

Rogers, A and Pilgrim, D (2014) A Sociology of Mental Health and Illness. (5th ed.) Maidenhead: Open University Press

Sennett, R (1998) The Corrosion of Character. New York and London: WW Norton and Company 
Skidelsky, R (2019) How To Achieve Shorter Working Hours. Lord Skidelsky, assisted by Rachel Kay. A Report Commissioned by the Rt. Hon. John McDonnell MP, Shadow Chancellor of the Exchequer pl-43

Standing, G (2014) A Precariat Charter. London: Bloomsbury

Stewart, H and Walker, P (2019) Yellowhammer: No -deal chaos fears as secret brexit papers published. The Guardian, September 12th

UEA (University of East Anglia) (2018) Critical Reinventions: 12 May. Programme for 2nd symposium on de-professionalisation held by UEA Centre for the Creative and the Critical Work Foundation (2018) Productivity, Technology and Working Anywhere. www. theworkfoundation.com Lancaster University. January 